\title{
Exploration in Bolivia: Discussion
}

\section{Author(s): G. E. Church, Colonel Suarez and Señor Aramayo}

Source: The Geographical Journal, Vol. 25, No. 5 (May, 1905), pp. 511-513

Published by: geographicalj

Stable URL: http://www.jstor.org/stable/1776690

Accessed: 26-06-2016 23:05 UTC

\section{Your use of the JSTOR archive indicates your acceptance of the Terms \& Conditions of Use, available at}

http://about.jstor.org/terms

JSTOR is a not-for-profit service that helps scholars, researchers, and students discover, use, and build upon a wide range of content in a trusted digital archive. We use information technology and tools to increase productivity and facilitate new forms of scholarship. For more information about JSTOR, please contact support@jstor.org.

The Royal Geographical Society (with the Institute of British Geographers), Wiley are collaborating with JSTOR to digitize, preserve and extend access to The Geographical Journal 
speculations as have appeared on the subject were due to a misinterpretation of certain phenomena.

Before the paper, the Chairman (Colonel G. E. Church) said : Our paper this evening is on a very interesting section of South America, through the northern part of the Argentine Republic, and skirting the foot of the hills of the Andes and various points in Bolivia. I will now call on Dr. Hoek to read his paper.

After the paper, the ChaIrMan said: We have the pleasure of having with us this evening Colonel Suarez, charge d'affaires of Bolivia. Perhaps he will favour us with a few remarks.

Colonel Suarez: I have listened with great pleasure to the very interesting lecture about Dr. Hoek's travels in Bolivia. I am very pleased indeed that some interest is being taken now in South America. It is not very long ago that $I$ was invited to a country house in England, and when I arrived there I only found the ladies of the house-party. They were all staring at me, and I could not make out what was the reason. But soon I discovered it. One of the ladies of the house-party brought me her album, and asked me to write my name down and the country from which I came. I did so, and after having written "Bolivia," she asked, "Something else?" I caid, "What?" "Something else?" I said, "South America?" "Yes," she said, "that is what we want." And then the lady of the house told me they had been discussing at length where Bolivia was; some said it was in South Africa, and some in Bohemia. When she told me this, I found out they expected to see me dressed in feathers. That is why I am so very thankful to Dr. Hoek, Colonel Church, and Sir Martin Conway, who have travelled there and given you some idea of Bolivia. You will see we are not quite in the state in which things were originally found. I hope at no distant date the country will be opened up with railways, and I dare say Messrs. Thomas Cook \& Son will be selling you tickets and taking you over to make a few excursions up the mountains. I may tell you we have all sorts of climates there; you can choose your own. We have not such a pretty climate as you have in England, where in a few hours you have five or six changes; but, all the same, I think we could offer you some very nice climates indeed. I heard Dr. Hoek's remark that the principal industry is mining. It is so; but I may tell you that we also have indiarubber. The indiarubber that comes from Bolivia they call Para rubber, because it passes through the port of Para; the best comes from Bolivia, and is then shipped to Europe. We also have great opening for agriculture, as to which Colonel Church will be able to inform you, for he was in Bolivia some years ago, and he took great interest in that country, and I hope he will still do so. In conclusion, I have only to thank Dr. Hoek for his lecture on Bolivia.

The Chairman: I also see our well-known friend, Señor Aramayo, late Minister of Bolivia.

Señor ARamayo: I thank you for calling upon me to say a few words on this occasion, but I have nothing to add to the feelings already expressed by Colonel Suarez on behalf of Bolivia. I have only to say that I thank Dr. Hoek for his very interesting lecture to-night, which has instructed me on many points respecting the geology and geography of my own country; and I am sure it is very satisfactory to see that the exploration conducted by my old friend Dr. Steinmann has been so successful in Bolivia, and has given an opportunity to this Society to hear a good deal of the interesting resources of the country.

The Chatrman: With your permission, I will occupy a few minutes of your time. I have read Dr. Hoek's paper carefully, and he is to be complimented on the information of varied character it contains. Once we get the accurate 
map of his travels, it will be a great advantage to the geography of the region of which he has treated. But his paper once more opens the old question of the glaciation of South America-an ice age, of which he says there were in the Andes three marked epochs. We know that, so far as North America is concerned, the ice-cap extended south to about $35^{\circ} \mathrm{N}$. lat. This paper brings forward prominently an ice age on the southern half of the continent, where glaciation extended north at least as far as $17^{\circ} \mathrm{S}$. lat., at a point in the valley of the Amazon at about 5000 feet above sea-level, north of Cochabamba. Here Dr. Hoek found numerous evidences of glacial action. The theory of Agassiz as to the glaciation of the Amazon valley and of all Brazil has been, to the satisfaction of most people, completely demolished by the studies of the gcological section of the Brazilian Government, and especially by the eminent geologist, Dr. John Branner. He has gone very thoroughly into this ice question, and finds that the crystalline rocks of Brazil, from Rio de Janeiro to the Amazon, are subject to a softening process. In the case of gneiss, granite, and diorite, the decomposition sometimes reaches a depth of more than 300 feet, and hard felspathic-porphyry is decomposed from 12 to 15 feet deep. Some of the Mincene rocks are decomposed to a depth of 370 feet, and in the carbonaceous formation as deep as 400 feet. This process splits off immense masses from the slopes of the mountains, and these are broken into fragmente, large and small, which exfoliate on their edges and form boulders, that are piled up in such profusion that well may they be taken for moraines. This was true of a mass of dioritic boulders that Agassiz found 400 or 500 miles up the Amazon, on the north side, and which he took as morainic formation, but which was afterwards discovered to be composed of boulders of decomposition. Similar deposits may be found all along the coast of Brazil inland, and have all been proven to be of the same nature. Such softening of the rocks in the South American tropics goes on at a much greater pace than it does in the temperate zone. For instance, the amount of nitric acid and carbonic acid in the atmosphere, and especially the former, is very great, and is said to be formed from the electric discharges of the atmosphere, and this helps the decomposition process. Again, something which seems to have deceived a great many geologists, and made them think they were looking upon traces of glacial action, is the "fluting," examples of which are numerous in the Brazilian rocks. A drop of water trickles down, and ultimately a little stream forms a groove, until finally in the course of ages it grows deeper and deeper-anywhere from 6 inches to many feet. If my statements be correct, one has to accept the glacial theory with reference to Brazil and any part of the Amazon valley with reserve; but $I$ have no doubt that the eminent gentlemen who have made these geological examinations now under discussion thoroughly understand that their views are in conflict with the geologists who have so exhaustively studied the problem of South American glaciation in Brazil. Dr. Hoek has been examining the slopes of the Andes-what shall I say? from $22^{\circ} \mathrm{S}$. lat. up to $17^{\circ}$, where he found glacial action at a very low elevation, at the Amazon base of the Tunari range. This point is 360 geographical miles nearer the equator than Rio de Janeiro, in the vicinity of which the mountains rise to the elevation of 10,040 feet, mountains of such friable material that, had they ever been glaciated, they would have melted like sugar. It seems doubtful if any isothermal lines could ever bave compensated for this difference of latitude and great elevation. But the glaciation of Brazil having been disproved, query, do we not require still further knowledge regarding these supposed glacial evidences reported from Bolivia before we can thoroughly accept the views set forth in Dr. Hoek's paper? May not his moraines also be boulders of decomposition? I do not assert that they are; but the question is interesting, and so able and devoted a scientist as Dr. Hoek will, I feel certain, 
make it more so in the future. I have simply thrown out a few ideas; but I may say to Dr. Hoek I am not a professional geologist, only an amateur; but the two sides of the continent seem to be so in contradiction that we hope we shall have more information from Dr. Hoek himself. I was going to ask him to give it to us now, but, as he seems to be a little shy of his good English, we must hope that he will favour us in some other form later on. In any event, I think I express your sentiments in thanking Dr. Hoek most heartily for his paper, and also the very excellent mouthpiece he has brought with him, who, I may say, has adorned science with the eloquence of poetry.

\section{A TRIP INTO THE CHILI PROVINCE, NORTH CHINA.*}

By the Rev. JOHN BEDLEY.

IT had long been my desire to take a trip through the Great Wall of China, and see for myself at least a part of that large tract of country known as the Chili Province. My travelling companion was Mr. R. J. Gould, sub-agent of the British and Foreign Bible Society in Tientsin, and the primary object of our journey was the dissemination of Scriptures. We started off from this ancient city of Yung-Phing fu (Eternal Peace), whose history can be traced back for 3000 years, on October 19, 1904.

Not only did we travel without escort, but without firearms of any description whatever, and when it is remembered that the district is proverbial for lawlessness, it says something for the local government that we were not once placed in any position where firearms would have been of value. The friendliness of the people was most marked.

On October 22 we passed through the wall at Lung-ko (Cold pass). Lŭng-ko is the only pass for some miles round possible for vehicular traffic. Several other passes, as Liu-chia-ko and Tao-lin-ko, are in the vicinity, but boulders lie so thick that it is impossible for carts or barrows to get through. Animals and foot-passengers, however, use these passes regularly, and so reach their destinations quicker than would be possible were they confined to only one exit. At all these places custom houses are found, and taxes levied on goods passing to and fro. Bıoks alone are exempt from duty, so we got through without any delay on that score. The pass at Lung-ko, through which the Sha Ho (Sand river) flows, no longer boasts the tower that once spanned the river, its place being taken by a sort of barrier made of inverted poles across the stream. The tower was destroyed by floods in the year 1850, and of course there has never been any attempt made to replace it. A very fine specimen of the ancient towers still stands at Liu-chia-ko, some 10 miles east of Lung-ko, of which a print was recently sent to the R.G.S.

* Map, p. 588.

No. V.-MAY, 1905.] 